\title{
ANALISIS TRUE CUSTOMER NEEDS PRODUK GREEN TEA CHOCOLATE BERDASARKAN INTEGRASI PRODUCT QUALITY DAN MODEL KANO PADA UKM ARAFA TEA
}

\author{
${ }^{1}$ Annisaa Rasyida, ${ }^{2}$ Yati Rohayati, ${ }^{3}$ Atya Nur Aisha \\ 1,2,3Program Studi Teknik Industri, Fakultas Rekayasa Industri, Telkom University \\ 1'rasyidable@gmail.com, ${ }^{2}$ yati.rohayati.ittelkom@gmail.com, ${ }^{3}$ atyanuraisha@gmail.com
}

\begin{abstract}
Abstrak-UKM Arafa Tea merupakan salah satu UKM di Bandung yang bergerak dalam produksi produk olahan teh, dengan Green Tea Chocolate (GTC) sebagai salah satu produk unggulannya. Pendapatan GTC mampu memberikan kontribusi terbesar dan memiliki perputaran uang paling cepat dibandingkan dengan produk olahan lainnya. Melihat kesempatan tersebut, UKM Arafa Tea berniat untuk memperluas pasarnya dengan mengembangkan pasar sekaligus memposisikan GTC sebagai jajanan olahan teh khas Bandung. Untuk melakukan hal tersebut, dilakukan penelitian menggunakan integrasi Product Quality dan Model Kano guna mengetahui kebutuhan dan kepuasan pelanggan GTC Arafa Tea. Penelitian bertujuan untuk menghasilkan output berupa rekomendasi true customer needs yang perlu diperhatikan sebagai upaya perbaikan yang harus dilakukan oleh Arafa Tea. Penelitian ini dilakukan dengan mengidentifikasi 21 atribut kebutuhan yang digunakan untuk mengukur kinerja eksisting Arafa Tea dan mengategorikannya berdasarkan dampak kepuasan yang diberikan. Berdasarkan hasil integrasi diperoleh bahwa terdapat sepuluh atribut kebutuhan GTC yang memiliki nilai kepuasan pelanggan yang lemah, yang terdiri dari dua atribut one-dimensional, tiga attractive dan lima atribut must-be. Seluruh atribut ini dianalisis dan disesuaikan dengan kapasitas yang dimiliki UKM guna memperoleh rekomendasi akhir true customer needs. Hasil analisis menunjukkan bahwa terdapat delapan true customer needs, diantaranya adalah peningkatan intensitas rasa cocoa, kesesuaian kombinasi rasa, peningkatan intensitas rasa manis, warna hijau yang menarik, penurunan intensitas rasa green tea, kejelasan pencantuman periode tanggal kedaluwarsa, penurunan intensitas rasa pahit dan kejelasan pencatuman merek yang menarik pada kemasan.
\end{abstract}

Kata kunci: kepuasan pelanggan, product quality, model kano

\section{PENDAHULUAN}

Arafa Tea adalah satu di antara banyak UKM yang berada di Kabupaten Bandung. UKM ini berfokus pada berbagai produk olahan teh, salah satunya adalah Green Tea Chocolate (GTC) Arafa Tea. Pada saat ini, UKM Arafa Tea sendiri memang sedang berfokus pada produk GTC Arafa Tea. Fokus ini dilatarbelakangi dengan pertimbangan bahwa GTC Arafa Tea merupakan produk yang paling mudah dikonsumsi dan memiliki perputaran uang yang paling cepat dibandingkan dengan produk olahan teh lain miliknya serta semakin maraknya makanan camilan serba green tea yang sedang tren di kalangan anak muda dan wisatawan di Kota Bandung.
Hasil wawancara dengan salah satu staf bagian produksi UKM Arafa Tea menyebutkan bahwa produk GTC Arafa Tea sendiri mampu menyumbangkan 50\% keseluruhan omzet yang diperoleh oleh Arafa Tea, namun hanya $20 \%$ saja omzetnya berasal dari GTC Arafa Tea level tiga [1]. Gambar 1 merupakan data pendapatan produk GTC Arafa Tea selama empat tahun terakhir.

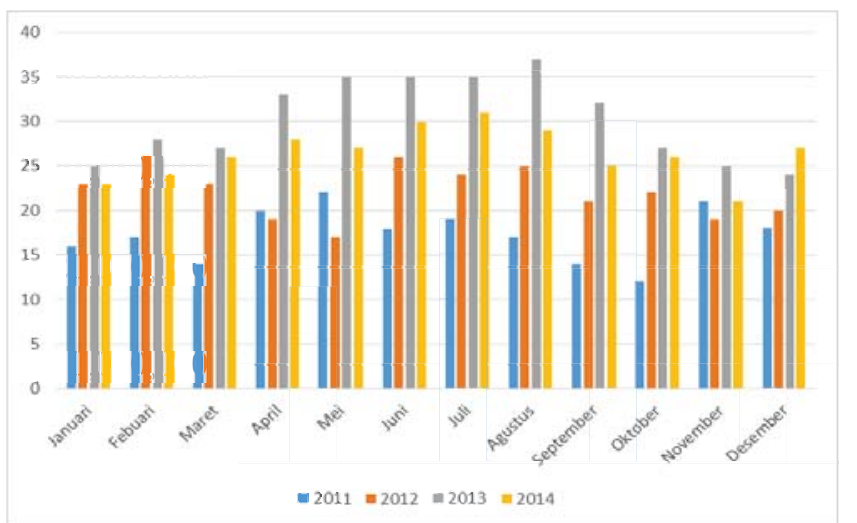

Gambar 1 Pendapatan Rata-rata GTC Arafa Tea 2011-2014

Gambar 1 menggambarkan bahwa pendapatan rata-rata produk GTC Arafa Tea cenderung fluktuatif selama empat tahun terakhir. Melihat kondisi tersebut, UKM Arafa Tea berencana untuk meningkatkan penjualan pada produk GTC Arafa Tea, terutama GTC level tiga. Untuk mencapai hal itu, Arafa Tea harus mengembangkan segmen pasarnya sekaligus memosisikan GTC sebagai jajanan olahan teh khas Bandung [1].

Untuk melakukan hal tersebut Arafa Tea perlu mengetahui keinginan dan kebutuhan pelanggan mengenai produk GTC Arafa Tea. Depth interview dilakukan sebagai metode survei pendahuluan sehingga diperoleh tanggapan terhadap produk GTC Arafa Tea. Berdasarkan survei tersebut diperoleh bahwa 47\% tidak menyukai produk GTC Arafa Tea. Berikut merupakan informasi-informasi keluhan yang memengaruhi ketidaksukaan responden atas produk GTC pada Tabel I.

Keluhan tersebut merupakan cerminan tidak terpenuhinya ekspektasi pelanggan atas produk yang ditawarkan sehingga melatarbelakangi hadirnya ketidakpuasan terhadap GTC Arafa Tea. Oleh karena itu, agar GTC Arafa Tea tetap bersaing dan unggul, 
diperlukan suatu identifikasi atribut kebutuhan pelanggan sehingga GTC Arafa Tea sesuai dengan harapan dan membantu memuaskan para pelanggannya.

TABEL I

JENIS KELUHAN PELANGGAN (SUMBER: SURVEI PENDAHULUAN, 2014)

\begin{tabular}{|c|c|c|}
\hline No. & Keluhan & Persen \\
\hline 1 & Rasa terlalu pahit dan kombinasi rasa tidak menyatu. & $50 \%$ \\
\hline 2 & Tekstur kasar dan tidak padat. & $29 \%$ \\
\hline 3 & Warna tidak menarik. & $7 \%$ \\
\hline 4 & Ukuran bar coklat terlalu kecil. & $14 \%$ \\
\hline
\end{tabular}

Salah satu cara untuk melakukan identifikasi kebutuhan pelanggan adalah dengan menggunakan integrasi Product Quality dan Model Kano. Hal ini mengacu pada penelitian serupa terdahulu yang menjelaskan bahwa Model Kano adalah metode yang dapat digunakan untuk mengetahui preferensi pelanggan dengan mengategorikan atribut-atribut barang atau jasa berdasarkan kemampuannya memuaskan pelanggan berdasarkan kategori Kano [2]. Model Kano menggunakan kuesioner terstruktur mengenai atribut produk untuk memperoleh klasifikasi atribut berdasarkan tingkat kepuasannya [3]. Model Kano sendiri cocok dengan relevansi penelitian yang bertujuan untuk mengembangkan produk, konsep penelitian seperti ini sudah dilakukan sebelumnya [4]. Model Kano menawarkan pemahaman yang sangat baik tentang bagaimana pelanggan mengevaluasi produk dan membantu perusahaan untuk lebih fokus pada atribut penting yang harus ditingkatkan [5], rencana bisnis suatu perusahaan dan pengembangan produk menuju inovasi, daya saing dan penyesuaian produk sehingga pasar semakin memiliki banyak pilihan dan menjadi lebih menuntut daripada sebelumnya [6][7]. Dilakukannya pengintegrasian Product Quality dan Model Kano digunakan untuk memeroleh hasil prioritas dari atribut produk yang harus diperbaiki ataupun ditingkatkan [8].

\section{METODE PENELITIAN}

D. Model Konseptual

Gambaran hubungan variabel-variabel yang digunakan pada penelitian digambarkan pada model konseptual pada Gambar 2.

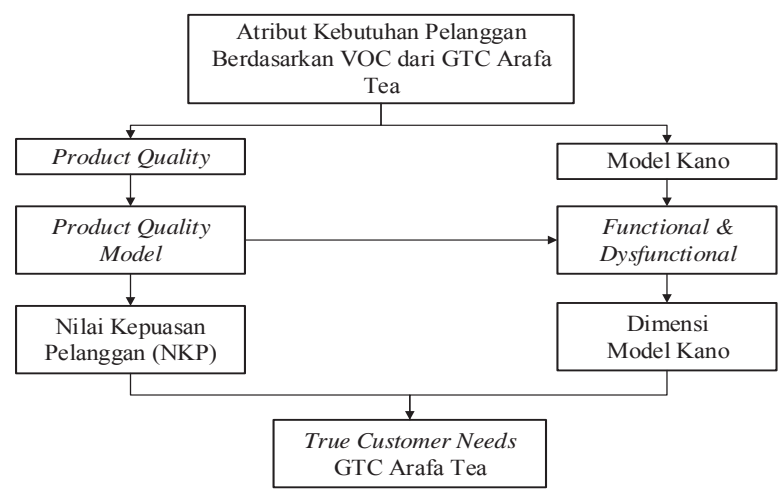

Gambar 2 Model konseptual

Pada penelitian dianalisis mengenai atribut kebutuhan pelanggan yang dikategorikan sebagai atribut true customer needs, dalam hal ini khususnya GTC Arafa Tea. Oleh karena itu, dibutuhkan variabel tersebut guna diklasifikasikan menggunakan Product Quality dan Model Kano. Data dan informasi mengenai atribut kebutuhan pelanggan dikategorikan berdasarkan dimensi Product Quality yang relevan dan digambarkan melalui model Product Quality.

\section{E. Model Konseptual}

Model Product Quality digunakan untuk membantu menggambarkan indikator yang digunakan dalam mengukur kualitas produk sebagai dasar perancangan instrumen penelitian, yaitu kuesioner. Model Product Quality pada penelitian sendiri digambarkan pada Gambar 2.

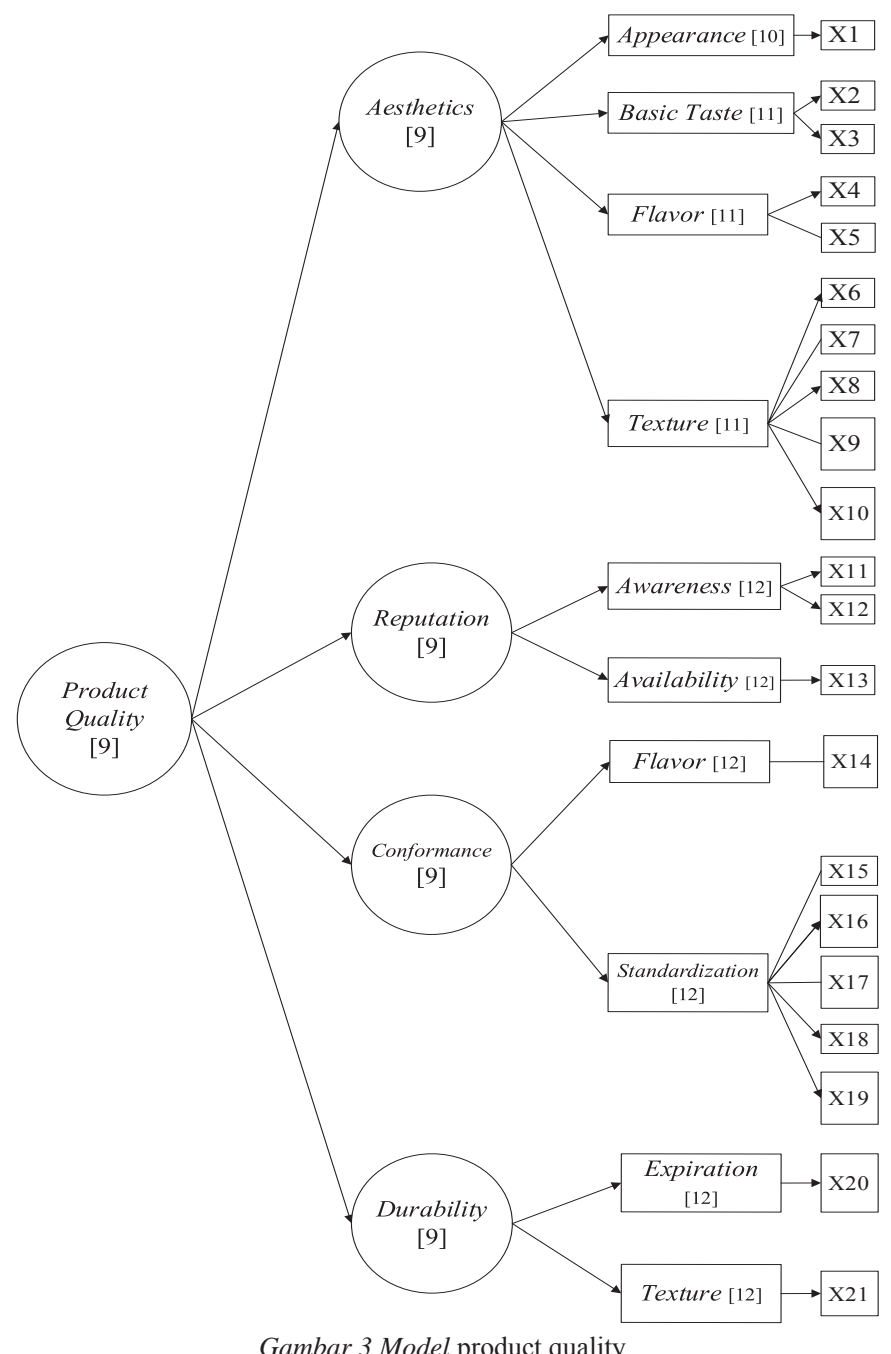

Keterangan:

X1 Appearance

X12 Visibility

$\mathrm{X} 2$ Sweetness

X13 Avalaibility

X3 Bitterness

X14 Overall flavor intensity

X4 Cocoa flavor intensity

X15 Standard bar size

X5 Green tea flavor intensity

$\mathrm{X} 6$ Bite resistance

X16 Health standard

X7 Crumbliness

X17 Nutritional standard

X8 Stickyness

X9 Melting time

X18 Halal standard

X19 Ingridients standard

X20 Expiration standard

X10 Mouth-coating

X11 Brand awareness
X21 Hardness 
Dimensi Product Quality yang digunakan adalah aesthetics, reputation, durability dan conformance [9]. Penentuan dimensi dan indikatornya didasarkan pada studi literatur pada penelitian serupa terdahulu, wawancara (VoC) dan analisis dari peneliti yang dijabarkan sebagai berikut.

a. Texture adalah gabungan dua buah elemen antara struktur fisik dan sifat permukaan dan mekanis suatu komposisi pangan yang saling berkombinasi satu sama lain menciptakan rasa di mulut ataupun indra perasa lainnya, yang biasa disebut mouthfeel [13].

b. Basic taste merupakan atribut yang paling banyak diterima secara umum oleh para penyuka produk pangan. Untuk atribut flavor, merupakan atribut penting dikarenakan atribut yang mengukur diferensiasi produk.

c. Tampilan (Appearance) pada warna adalah salah satu atribut kualitas utama karena menunjukkan karakteristik dari komposisi suatu produk pangan. Warna mampu memberikan informasi tentang komposisi kimia, proses pengolahan dan ketahanan produk itu sendiri [14].

d. Standardization memiliki peranan penting untuk memberikan informasi produk dalam proses pembuatannya. Produk pangan wajib memiliki standardisasi yang telah ditetapkan pihak yang berwenang sehingga produk pangan tersebut bisa dipasarkan oleh produsen. Standar ini meliputi aspek pengawasan dan sanitasi.

Indikator dan VoC yang diperoleh merupakan dasar pembuatan instrumen penelitian berupa kuesioner. Kuesioner dibagi menjadi dua jenis, yakni kuesioner Product Quality \& Model Kano. Kuesioner Product Quality digunakan untuk memperoleh Nilai Kepuasan Pelanggan (NKP). NKP ini diperoleh berdasarkan nilai kepuasan, harapan dan kepentingan dari setiap indikator dimensi yang diuji. Secara berturut-turut NKP positif dan negatif menghasilkan atribut kuat dan atribut lemah [8]. Kuesioner Model Kano dilakukan guna membantu menentukan atribut bergolongan must-be, onedimensional, attractive, indifferent, reverse atau questionable dengan menggunakan tabel evaluasi Model Kano dan formula Blauth [15]. Pengelompokan antarkeduanya (Product Quality \& Model Kano) kemudian dikombinasi/diintegrasikan menghasilkan true customer needs terhadap produk GTC Arafa Tea.

\section{HASIL DAN PEMBAHASAN}

Penelitian ini bertujuan untuk mengetahui rumusan rekomendasi true customer needs yang dibutuhkan oleh UKM Arafa Tea guna mengembangkan GTC berdasarkan dampak kepuasan yang diberikan dari setiap atribut yang sudah berhasil diidentifikasi pada awal penelitian. Pengolahan data yang dilakukan terdiri dari perhitungan nilai kepuasan pelanggan pada kuesioner Product Quality dan pengolahan Model Kano.

\section{A. Hasil Identifikasi Atribut Kebutuhan}

Identifikasi atribut kebutuhan pelanggan diperoleh melalui kegiatan depth interview yang bertujuan untuk mendapatkan feedback langsung, lebih mendalam dan memberikan kebebasan dalam mengutarakan opini dari responden [16]. Target responden adalah responden anak muda berdomisili di Bandung dengan karakteristik utama pernah mengonsumsi GTC. Jawaban proses wawancara tersebut merupakan VoC dari produk GTC dan dapat menghasilkan jawaban yang bervariasi dan memiliki hubungan antarsatu sama lain. Oleh karena itu, dibutuhkan diagram afinitas sebagai alat untuk mengklarifikasi kebutuhan apa yang responden benar-benar butuhkan [17]. Tabel 2 merupakan atribut kebutuhan GTC Arafa Tea.

TABEL II

ATRIBUT KEBUTUHAN GTC ARAFA TEA

\begin{tabular}{|c|c|}
\hline Atribut Kebutuhan & Kode \\
\hline $\begin{array}{l}\text { Tekstur GTC memiliki ketahanan gigit dengan gigi } \\
\text { depan (Bite resistance) }\end{array}$ & AES01 \\
\hline GTC bisa dipotong menjadi potongan kecil di mulut & $\mathrm{AES} 02$ \\
\hline GTC memberikan sensasi rasa lengket/sticky & AES03 \\
\hline Coklat tidak lumer setelah lebih dari tiga kali kunyahan & $\mathrm{AES04}$ \\
\hline Coklat memberikan rasa kesat di mulut setelah ditelan & $\mathrm{AES} 05$ \\
\hline $\begin{array}{l}\text { Intensitas kombinasi semua rasa (green tea dan coklat) } \\
\text { sesuai dengan yang diinginkan }\end{array}$ & AES06 \\
\hline Kesesuaian intensitas rasa coklat (cocoa) & AES07 \\
\hline Kesesuaian intensitas rasa green tea & AES08 \\
\hline Kesesuaian intensitas rasa manis (sweetness) & AES09 \\
\hline Kesesuaian intensitas rasa pahit (bitterness) & AES10 \\
\hline Warna hijau GTC menarik untuk dikonsumsi & AES11 \\
\hline $\begin{array}{l}\text { Terdapat label lolos uji kesehatan PIRT BPOM pada } \\
\text { kemasan GTC }\end{array}$ & CON01 \\
\hline Terdaoat label halal MUI pada kemasan GTC & $\mathrm{CON} 02$ \\
\hline $\begin{array}{l}\text { GTC mencantumkan komposisi bahan baku pada } \\
\text { kemasan }\end{array}$ & CON03 \\
\hline Ukuran GTC saat ini sesuai dengan yang diinginkan & CON04 \\
\hline Coklat tidak mudah lembek & DUR01 \\
\hline $\begin{array}{l}\text { Coklat mencantumkan periode kedaluwarsa yang jelas } \\
\text { pada kemasan }\end{array}$ & DUR01 \\
\hline Ketersediaan produk di berbagai outlet & REP01 \\
\hline Informasi mengenai keberadaan outlet mudah diperoleh & REP03 \\
\hline $\begin{array}{l}\text { Pencantuman merek yang menarik jelas tercantum pada } \\
\text { kemasan GTC }\end{array}$ & REP03 \\
\hline
\end{tabular}

\section{B. Hasil Pengolahan Product Quality}

Proses pengolahan data dilakukan dengan menghitung gap yang terjadi melalui perhitungan selisih antara nilai kepuasan dan nilai harapan pelanggan. Hasil yang diperoleh kemudian akan dikalikan dengan nilai kepentingan pelanggan, sehingga menghasilkan nilai kepuasan pelanggan (NKP) [8]. NKP positif dikategorikan sebagai atribut kuat, sedangkan NKP negatif dikategorikan sebagai atribut lemah.

Berdasarkan hasil pengolahan Product Quality diperoleh bahwa terdapat lima atribut berkategori kuat dan enam belas atribut berkategori lemah. Atribut yang berkategori kuat mengindikasikan atribut tersebut dalam kondisi eksisting sudah mampu memenuhi kepuasan pelanggan sedangkan atribut berkategori lemah menunjukkan bahwa atribut tersebut masih memiliki kinerja di bawah kepuasan pelanggan.

\section{Hasil Pengolahan Model Kano}

Pengolahan Model Kano terdiri dari dua bagian, yaitu kuesioner fungsional dan disfungsional. Keduanya dilakukan pengolahan secara bersamaan untuk memeroleh kategorisasi pada atribut-atribut yang 
diperoleh menggunakan tabel evaluasi Model Kano yang ditunjukkan pada Gambar 4 dan perhitungan menggunakan Blauth's formula [12] sebagai berikut:

$$
\sum(O+A+M)>\sum(I+R+Q)
$$

Maka penentuan kategori Kano diperoleh dari nilai yang paling besar di antara one dimensional, attractive atau must be.

$$
\sum(O+A+M)<\sum(I+R+Q)
$$

Maka penentuan kategori Kano diperoleh dari nilai yang paling besar di antara indifferent, reverse atau questionable.

$$
\sum(O+A+M)=\sum(I+R+Q)
$$

Maka penentuan kategori Kano diperoleh dari nilai yang paling besar di antara semua kategori Kano, yaitu one dimensional, attractive, must be, indifferent, reverse atau questionable.

\begin{tabular}{|c|c|c|c|c|c|c|}
\hline \multirow{2}{*}{\multicolumn{2}{|c|}{$\begin{array}{l}\text { Customer } \\
\text { Needs }\end{array}$}} & \multicolumn{5}{|c|}{ Dysfunctional } \\
\hline & & Like & Must-be & Neutral & Live With & Dislike \\
\hline \multirow{5}{*}{ 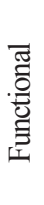 } & Like & Q & A & A & A & $\mathrm{O}$ \\
\hline & Must-be & $\mathrm{R}$ & I & I & I & M \\
\hline & Neutral & $\mathrm{R}$ & I & I & I & M \\
\hline & Live With & $\mathrm{R}$ & I & I & I & M \\
\hline & Dislike & $\mathrm{R}$ & $\mathrm{R}$ & $\mathrm{R}$ & $\mathrm{R}$ & Q \\
\hline
\end{tabular}

TABEL III

TABEL EVALUASIMODEL KANO

A: Attractive; O: One-Dimensional; M: Must-be; Q: Questionable; R: Reverse; I: Indifferrent

Berdasarkan hasil pengolahan atribut menggunakan Model Kano, maka dapat diketahui bahwa dari 21 atribut yang berhasil teridentifikasi pada awal penelitian terdapat delapan atribut berkategori indifferent, dua atribut berkategori one-dimensional, tiga atribut attractive dan delapan atribut must-be.

\section{Pembahasan dan Diskusi}

Setelah diperoleh kategorisasi untuk masing-masing atribut, selanjutnya dilakukan analisis dan perumusan rekomendasi berupa atribut yang harus dikembangkan dan diperbaiki. Perumusan ini dilakukan dengan mengintegrasikan NKP yang diperoleh dari pengolahan kuesioner Product Quality dengan kategori Kano yang diperoleh pada tahap sebelumnya. Hasil integrasi keduanya akan menghasilkan true customer needs dari GTC Arafa Tea. True customer needs dikategorikan sebagai atribut berkategori attractive, baik yang memiliki nilai kepuasan pelanggan yang lemah ataupun kuat serta atribut berkategorikan one-dimensional dan must-be yang memiliki nilai kepuasan pelanggan yang lemah. True customer needs berkategori attractive memiliki prioritas perbaikan untuk dikembangkan, sedangkan true customer needs berkategori onedimensional dan must-be memiliki prioritas perbaikan untuk diperbaiki/ditingkatkan kinerjanya. True customer needs yang diperoleh dari hasil integrasi tersebut ditunjukkan pada Tabel IV dan Tabel V.
TABEL IV

TRUE CUSTOMER NEEDS GTC ARAFA TEA DIKKEMBANGKAN

\begin{tabular}{|c|c|c|}
\hline No. & Kode & $\begin{array}{c}\text { True Customer Needs yang Perlu } \\
\text { Dikembangkan }\end{array}$ \\
\hline 1 & A & Ukuran standar bar GTC \\
\hline
\end{tabular}

Berdasarkan hasil integrasi yang dilakukan, atribut ini sudah mampu memenuhi kepuasan pelanggan karena memiliki NKP yang positif. Atribut attractive mengindikasikan bahwa atribut kebutuhan standar ukuran coklat menjadi atribut yang mampu memberikan kepuasan secara signifikan jika atribut ini diimplementasikan pada Coklat GTC

\begin{tabular}{|c|c|c|}
\hline No. & Kode & True Customer Needs yang Perlu Diperbaiki \\
\hline 1 & $\mathrm{O}$ & $\begin{array}{l}\text { Kesesuaian intensitas cocoa coklat pada } \\
\text { GTC (chocolate flavor intensity) }\end{array}$ \\
\hline 2 & $\mathrm{O}$ & $\begin{array}{l}\text { Kombinasi rasa green tea dan coklat secara } \\
\text { keseluruhan (overall flavor combination) }\end{array}$ \\
\hline 3 & M & $\begin{array}{l}\text { Kesesuaian intensitas rasa manis pada coklat } \\
\text { GTC. } \\
\text { (sweetness) }\end{array}$ \\
\hline 4 & A & $\begin{array}{l}\text { Warna hijau pada GTC menarik untuk } \\
\text { dikonsumsi. }\end{array}$ \\
\hline 5 & A & $\begin{array}{l}\text { Kesesuaian intensitas rasa green tea pada } \\
\text { coklat. }\end{array}$ \\
\hline 6 & M & $\begin{array}{l}\text { Kejelasan pencamtuman periode tanggal } \\
\text { kedaluwarsa coklat GTC. }\end{array}$ \\
\hline 7 & M & $\begin{array}{l}\text { Kesesuaian intensitas rasa pahit pada coklat } \\
\text { GTC (bitterness) }\end{array}$ \\
\hline 8 & M & $\begin{array}{l}\text { Pencantuman merek produk pada kemasan } \\
\text { GTC. }\end{array}$ \\
\hline 9 & M & Konsistensi tekstur (hardness) \\
\hline
\end{tabular}

TABEL V

TRUE CUSTOMER NEEDS GTC ARAFA TEA DIPERBAIKI

\section{Chocolate Flavor Intensity}

Berdasarkan hasil uji coba rasa yang dilakukan pada awal penelitian, banyak dari responden yang mengeluhkan lemahnya intensitas sensasi coklat yang dirasakan, rasa tersebut terkalahkan dengan rasa green tea yang terlalu dominan, terutama pada saat fasa mouthfeel dan aftertaste. Atribut ini bersifat one-dimensional, kepuasan pelanggan akan berjalan linear sesuai dengan bagaimana Arafa Tea mampu merealisasikan atribut ini dengan baik. Oleh karena itu, UKM Arafa Tea perlu meningkatkan kinerja atribut ini.

\section{Overall Flavor Combinations}

Persepsi rasa yang dirasakan pada saat mengonsumsi GTC sangat dipengaruhi secara signifikan dari interaksi perpaduan sensoris, baik dari segi rasa maupun aroma sangatlah kuat dalam memengaruhi rasa yang diterima (appropriate perceived flavor) oleh pelanggan secara keseluruhan. Penggunaan rasio green tea yang tinggi (30 cocoa: 70 green tea) mampu memberikan sensasi yang diinginkan, baik dari segi rasa green tea yang terasa ataupun konsistensi tekstur, namun memiliki kekurangan, salah satunya adalah rasa green tea yang sangat overpowering, terutama pada saat fase aftertaste. Hal ini tidak dikehendaki pelanggan, terbukti dengan hasil pengolahan yang menunjukkan atribut kombinasi rasa sebagai atribut one-dimensional, jika atribut ini mampu direalisasikan dengan baik oleh UKM Arafa 
Tea, pelanggan akan merasa puas. Oleh karena itu, UKM Arafa Tea perlu meningkatkan kinerja atribut ini.

\section{Intensitas Rasa Manis}

Sweetness adalah salah satu dari lima rasa dasar yang dianggap sebagai pengalaman yang menyenangkan, sehingga merupakan hal yang sangat esensial jika atribut ini mampu memberikan kinerja yang baik dengan intensitas yang cukup. Ketidakhadiran atribut ini akan menyebabkan ketidakpuasan, sedangkan kehadirannya tidak akan berpengaruh apa pun pada kepuasan pelanggan, hal ini mengindikasikan bahwa atribut tersebut merupakan atribut dasar yang wajib ada pada produk GTC (must-be).

\section{Warna yang Menarik}

Warna melambangkan penampilan visual yang menarik, merangsang pandangan, rasa \& penciuman dan merupakan suatu hal yang penting untuk menarik minat pembeli. Atribut ini merupakan salah satu yang memberikan pengaruh yang cukup signifikan dalam penilaian GTC di mata pelanggan. Hal ini dibuktikan pula dengan hasil pengolahan yang mengategorikan atribut kebutuhan ini sebagai kategori attractive, yang berarti atribut kebutuhan ini merupakan atribut yang mampu meningkatkan kepuasan secara signifikan jika direalisasikan oleh UKM Arafa Tea.

\section{Intensitas Rasa Green Tea}

Keinovatifan rasa GTC diterima secara umum, namun terdapat beberapa keluhan yang dihadapi, di antaranya adalah keluhan cita rasa green tea yang sangat dominan, sehingga menghasilkan rasa pahit yang bertahan lama. Ketidakhadiran atribut ini tidak akan berpengaruh pada ketidakpuasan pelanggan, namun pelanggan akan merasa sangat puas jika atribut ini mampu direalisasikan dengan baik pada GTC Arafa Tea. Oleh karena itu, Arafa Tea perlu menyesuaikan kembali konsentrasi yang diberikan guna meningkatkan kepuasan pelanggan secara signifikan, karena atribut ini dapat membantu mendiferensiasikan GTC dari produk serupa lainnya.

\section{Pencantuman Informasi Tanggal Kedaluwarsa}

Informasi pencantuman periode kedaluwarsa adalah informasi mengenai batas akhir suatu produk pangan untuk dikonsumsi sebelum akhirnya rusak dan sudah tidak bisa dikonsumsi kembali. Informasi ini meliputi informasi tanggal, bulan dan tahun kedaluwarsa yang tercantum secara jelas pada kemasan. Berdasarkan hasil penggalian informasi pada pelanggan, informasi mengenai periode kedaluwarsa merupakan aspek informasi kemasan yang sangat penting dan bersifat dasar. Hal ini dibuktikan dengan hasil pengolahan yang menyatakan bahwa atribut kebutuhan penulisan periode kedaluwarsa termasuk ke dalam kategori must-be.

\section{Intensitas Rasa Pahit}

Tingkat rasa pahit pada coklat berbeda-beda dari satu pelanggan terhadap pelanggan lainnya, tergantung pada preferensi jenis coklat yang diinginkan. Banyak dari pelanggan yang mengeluhkan rasa pahit yang memiliki konsentrasi yang sangat tinggi, rasa pahit lebih cenderung memberikan sensasi rasa aspirin yang bertahan sangat lama di mulut pelanggan. Hal ini dibuktikan dengan hasil pengolahan data yang menunjukkan atribut ini sebagai kategori must-be, pelanggan meyakini atribut ini sebagai atribut fundamental yang wajib ada pada GTC. Hal ini bersifat wajar mengingat GTC sebagai paduan coklat dan green tea secara keseluruhan memberikan sensasi rasa yang sangat kompleks, tingkat kepahitan dan manis yang dikontribusikan oleh masing-masing komponen menjadi hal yang sangat penting untuk diterimanya rasa GTC secara keseluruhan (overall profile flavor) [18].

\section{Pencantuman Merek Produk yang Menarik}

Merek produk pada kemasan memiliki peranan penting sebagai bentuk identitas produk, terutama dalam hal ini adalah GTC Arafa Tea. Merek dapat meliputi nama, simbol, desain grafis ataupun kombinasi keseluruhannya untuk membedakannya dari produk kompetitor. Berdasarkan hasil penggalian informasi pada pelanggan, fungsi kemasan haruslah mampu menyampaikan informasi yang bersangkutan mengenai identitas produk, baik dari segi ciri, diferensiasi ataupun kualitas produk sehingga mempermudah pelanggan untuk merasa tertarik terhadap produk dibandingkan dengan merek produk lain yang serupa. Hasil pengolahan menunjukkan bahwa atribut kebutuhan kejelasan pencantuman merek produk yang menarik merupakan atribut berkategori must-be, yang mengindikasikan bahwa Arafa Tea perlu meningkatkan kinerja atribut ini guna terus memenuhi kepuasan pelanggan.

\section{Konsistensi Tekstur}

Ketika dilakukan pengumpulan data mengenai tingkat kesukaan dan penerimaan pelanggan mengenai kemungkinan terjadinya blooming pada Coklat GTC, hasil menunjukkan bahwa pelanggan tidak menghendaki terjadinya blooming karena memberikan kesan penampakan yang kurang baik, produk tidak tahan terhadap panas pada suhu lingkungan tertentu, sehingga muncul tekstur yang tidak konsisten walaupun masih berada dalam masa penggunaan [19]. Hal ini dibuktikan dengan atribut tergolong sebagai atribut must-be, yang berarti bahwa atribut ini merupakan atribut dasar yang harus ada pada GTC yang bersifat fundamental dan esensial. Ketidakhadiran atribut ini akan membuat pelanggan kecewa, sedangkan kehadirannya merupakan hal yang normal (biasa). Oleh karena itu, UKM Arafa Tea perlu meningkatkan kinerja atribut ini untuk memenuhi preferensi pelanggan.

TABEL VI

REKOMENDASI AKHIR TRUE CUSTOMER NEEDS

\begin{tabular}{|l|c|c|}
\hline Rekomendasi Akhir TCN & NKP & Kano \\
\hline $\begin{array}{l}\text { Kesesuaian intensitas cocoa coklat pada } \\
\text { GTC. }\end{array}$ & -4.00 & $\mathrm{O}$ \\
\hline $\begin{array}{l}\text { Kombinasi rasa green tea dan coklat secara } \\
\text { keseluruhan (overall flavor combination) }\end{array}$ & -2.79 & $\mathrm{O}$ \\
\hline $\begin{array}{l}\text { Kesesuaian intensitas rasa manis pada } \\
\text { coklat GTC. } \\
\text { (sweetness) }\end{array}$ & -2.71 & $\mathrm{M}$ \\
\hline $\begin{array}{l}\text { Warna hijau pada GTC menarik untuk } \\
\text { dikonsumsi. }\end{array}$ & -2.10 & $\mathrm{~A}$ \\
\hline $\begin{array}{l}\text { Kesesuaian intensitas rasa green tea pada } \\
\text { coklat. }\end{array}$ & -2.00 & $\mathrm{~A}$ \\
\hline $\begin{array}{l}\text { Kejelasan pencamtuman periode tanggal } \\
\text { kedaluwarsa coklat GTC. }\end{array}$ & -1.81 & $\mathrm{M}$ \\
\hline $\begin{array}{l}\text { Kesesuaian intensitas rasa pahit pada coklat } \\
\text { GTC (bitterness) }\end{array}$ & -1.42 & $\mathrm{M}$ \\
\hline $\begin{array}{l}\text { Pencantuman merek produk pada kemasan } \\
\text { GTC. }\end{array}$ & -1.37 & $\mathrm{M}$ \\
\hline
\end{tabular}


Perumusan rekomendasi akhir true customer needs terhadap GTC Arafa Tea didasarkan pada hasil analisis true customer needs yang diperoleh pada tahap sebelumnya dan diverifikasi langsung terhadap pihak UKM serta disesuaikan dengan kapasitas, kemampuan dan sumber daya UKM Arafa Tea dalam merealisasikan perbaikanperbaikan atribut yang perlu dilakukan. Pada perumusan ini, terdapat beberapa reduksi yang dilakukan, di antaranya pada atribut ukuran standar bar coklat serta pada atribut konsistensi tekstur GTC. Atribut ini masih belum mampu direalisasikan oleh Arafa Tea karena pertimbangan keterbatasan teknologi dan faktor biaya yang dimiliki oleh Arafa Tea. Berdasarkan hal tersebut, diperoleh bahwa terdapat delapan atribut true customer needs akhir yang bisa diimplementasikan oleh pihak UKM yang ditunjukkan secara rinci pada Tabel VI.

\section{KESIMPULAN}

Penelitian ini berhasil menjabarkan 21 atribut kebutuhan pelanggan yang dikelompokkan menjadi empat dimensi Product Quality, yaitu aesthetics, conformance, durability dan reputation. Dari keseluruhan atribut yang berhasil teridentifikasi terdapat enam belas atribut yang memiliki kinerja di bawah kepuasan pelanggan dan lima atribut sudah mampu memenuhi kepuasan pelanggan. Atribut-atribut tersebut diklasifikasikan menjadi tiga atribut attractive, dua atribut one-dimensional, delapan atribut must-be dan delapan atribut indifferent. Dari keseluruhan atribut tersebut Arafa Tea perlu melakukan perbaikan pada delapan atribut utama, diantaranya adalah kecocokan kombinasi antara rasa green tea dan coklat (overall flavor combination), peningkatan intensitas rasa cocoa coklat (cocoa flavor intensity), pengurangan intensitas rasa green tea pada GTC (green tea flavor intensity), peningkatan intensitas rasa manis pada coklat (sweetness), pengurangan intensitas rasa pahit pada coklat (bitterness), warna hijau GTC yang menarik untuk dikonsumsi, pencatuman tanggal kedaluwarsa dan pencatuman merek produk yang proporsional. Seluruh delapan atribut yang disebutkan merupakan atribut yang bersifat true customer needs. Atribut-atribut ini memiliki prioritas perbaikan yang lebih tinggi dibandingkan dengan sisa atribut yang lain karena pada pertimbangan kemampuan Arafa Tea guna membantu perusahaan untuk memenuhi kepuasan pelanggan.

\section{DAFTAR PUSTAKA}

[1] Raya, H. (2014, Oktober 4). Data dan Informasi Internal UKM Arafa Tea. (A. Rasyida, Interviewer)

[2] Rosa, S. E., Hidayat, A., \& Ikasari, D. M. (2013). Analisis Preferensi Pelanggan Terhadap Produk Kebab dengan Metode Kano (Studi Kasus di Outlet "Kayana Kebab \& Burger", Malang). 2.

[3] Mikulic, J., \& Prebezac, D. (2011). “A Critical Review of Techniques for Classifying Quality Attributes in the Kano Model”. Managing Service Quality Vo.21, No.1, 48.

[4] Matzler, K., \& Hinterhuber, H. H. (1998). "How to Make Product Development Projects More Successful by Integrating Kano's Model of Customer Satisfaction Into Quality Function Deployment". Technovation Vol.18 No.1, 30.
[5] Gustafsson, A., Ekdahl, F., \& Edvardsson, B. (1999). "Customer Focused Service Development in Practice". Internation Journal of Service Industry Management, Vol.10 No.4, 344-358.

[6] Seder, A. M., \& Alhazza, M. H. (2014). "Review on The Theory of Attractive Quality Kano Model". Journal of Advanced Science and Engineering Research Vol.4, No.2, 88-102.

[7] Verduyn, D. (2015). "Kano Model". Diambil dari Kano Model Web site: http://www.kanomodel.com/wpcontent/uploads/2014/03/KanoArticle_2013. pdf, diakses 20 Februari 2015.

[8] Tan, K. C., \& Pawitra, T. A. (2001). "Integrating SERVQUAL and Kano's Model Into QFD for Service Excellence Development". Managing Service Quality.

[9] Garvin, D. A. (1987). "Competing on the Eight Dimensions of Quality". In D. A. Garvin, Harvard Business Review (pp. 104-107).

[10] Melo, L. L., Bolini, H. M., \& Efraim, P. (2009). "Sensory Profile, Acceptability, and Their Relationship for Diabetic/Reduced Calorie Chocolates". Journal of Food Quality and Preference, 140.

[11] Haedelt, J., Beckett, S., \& Niranjan, K. (2007). "BubbleIncluded Chocolat: Relating Structure With Sensory Response". Journal of Food Science; Food Engineering and Physical Properties, 1-5.

[12] Fiani, M., \& Japarianto, E. (2012). Analisis Pengaruh Food Quality dan Brand Image Terhadap Keputusan Pembelian Roti Kecik Toko Roti Ganep's di Kota Solo. Jurnal Manajemen Pemasaran, 1-6.

[13] Szczesniak, A. S. (2002). "Texture is A Sensory Property". Journal of Food Science, 215-225.

[14] Zapotoczny, P., Kawatko, T., \& Bakier, S. (2010). "Determination of The Physical Characteristics of Food Raw Materials by Spectrophotometry". Journal of Technical Sciences, No. 13, 41.

[15] Berger, C., Blauth, R., Boger, D., Bolster, C., Burchill, G., DuMouchel, W., Walden, D. (1993). "Kano's Methods for Understanding Customer-defined Quality". Center for Quality of Management Journal, 4-8.

[16] Malhotra, N. K., \& Birks, D. F. (2007). Marketing Research An Applied Approach 3rd Edition. Harlow: Prentice Hall, Inc.

[17] Mazur, G. H. (1993). "QFD for Service Industries: From Voice of Customer to Task Deployment". The Fifth Symposium on Quality Function Deployment.

[18] Harwood, M. L., Loquasto, J. R., Roberts, F. R., Ziegler, G. R., \& Hayes, E. J. (2013). "Explaining Tolerance for Bitterness in Chocolate Ice Cream Using Solid Chocolate Preferences". Journal of Dairy Science Vol. 96 No. 8, 4939.

[19] Deliana, Susilo, B., \& Yulianingsih, R. (2014). "Analysis of Physical and Sensory Characteristic of Chocolate Candy from the Defated Peanut Powder Composition and Porang Flour (Amorphophallus Oncophyllus)". Jurnal Bioproses Komoditas Tropis, 63. 